\title{
Federal Public Administration Implementation in Vocational Education
}

\author{
Elena Y. Levina ${ }^{1}$, Aislu B. Yunusova ${ }^{2}$, Albina R. Fayzullina ${ }^{3}$, Sergey V. Rassadin ${ }^{4}$, Marat R. Lotfullin ${ }^{5}$, Elvira N. \\ Nuriyeva $^{6}$ \& Vera K. Vlasova ${ }^{5}$ \\ ${ }^{1}$ The Institute of Pedagogic and Psychology of Professional Education of Russian Academy of Education, Kazan, \\ Russia \\ ${ }^{2}$ R. G. Kuzeev Institute for Ethnological Studies, Ufa Scientific Center of the Russian Academy of Sciences, Ufa, \\ Russia \\ ${ }^{3}$ Kazan (Volga region) Federal University, Kazan, Russia \\ ${ }^{4}$ Tver State Technical University, Tver, Russia \\ ${ }^{5}$ Kazan State Agrarian University, Kazan, Russia \\ ${ }^{6}$ Nizhnekamsk Institute of Chemical Engineering, The branch of Kazan National Research Technological \\ University, Nizhnekamsk, Russia
}

Correspondence: Elena Y. Levina, The Institute of Pedagogic and Psychology of Professional Education of Russian Academy of Education, Kazan, Russia.

Received: December 29, 2014 Accepted: January 22, 2015 Online Published: February 11, 2015

doi:10.5539/res.v7n4p98

URL: http://dx.doi.org/10.5539/res.v7n4p98

\begin{abstract}
The transition to federal public administration in the Russian education system is determined by the legislation and presupposes responsible participation and interaction in education management of all educational agents. In the presented article an analysis has been carried out on the status of one of the federal public administration factors - information transparency of vocational and higher educational institutions. The paper defines the information realm of educational institutions from the perspective of educational services customers; there have been set the priorities for action in the field of transition to federal public administration of educational institutions. This article is written for managers and employees of the education authorities, educational institutions, as well as for all professionals and individuals interested in developing the Russian education system.
\end{abstract}

Keywords: federal public administration of education, educational institutions, educational agents, information transparency, interaction

\section{Introduction}

\subsection{Background}

At each stage of the society development, the education system status is determined by trends in socioeconomic development and technological structures of the economy development, there appear to be new conditions, opportunities and needs (financial; legal/regulatory; scientific/technical; organizational; informational; motivational, and others). At each alteration of other systems the conditions and objectives for implementing education are changing (Webster, 2004). The current socio-economic processes set before the education system and each educational institution innovation problems of not only educational level, but also of economic one: on educational institutions entering into the market economy, the conquest of the educational market niche while maintaining the traditions of learning. Besides, a specific set of motivated groups (stakeholders) is formed for the educational system, which can include: authorities, business structures, students, society, and teaching staff of educational institutions, influencing the formation of internal and external environment of the educational system (Danilova, 2002). In this case, the educational system as a whole and each educational organization should ensure the transparency of education for the objective competition development, structure and protect the interests of stakeholders with regard to their interaction, the inevitably emerging conflict of interests and influence levels (Jamil, 2009; Tsyvin, 2008; Waldman, 2010; Bochkarev, 2003). 


\subsection{Status of the Problem}

The necessary interaction of public and state forms of administration requires a change in the approach of informational interaction and insuring the information transparency of educational institutions functioning (Kosaretsky, 2010; Zhurenkov, 2007; Waldman, 2010).

As the regulatory basis of research the Law on Education of the Russian Federation comes forward, declaring the transition from federal administration to the federal public education administrative system that respects interests of all educational agents (stakeholders).

Modernization of the educational administration system involves creation of a flexible and efficient system of federal public administration at the federal, regional and municipal levels, as well as in educational institutions (Grishina,2007; Batsyn, 2009; Bolotov \& Waldman., 2012). The transition to federal public education has also been legally established, but there are considerable difficulties in its implementation, lack of experience, rules and regulations of public administration.

At the same time, the educational system should structure and protect the interests of stakeholders with regard to their interrelation, inevitably emerging conflict of interests and influence levels (Shimutina, 2013).

\subsection{Analysis of Foreign Experience as of Informing Different Groups of Educational Services Consumers}

Foreign non-governmental organizations, as well as financial, are included in the general system of stakeholders' interaction and on the basis of the implemented provisions of AA1000SES standard, which is on interaction with the parties concerned, ensure activity transparency, as they subject to the same financial laws and effect a sale/delivery of educational services (Kellagann, 2014).

Access to information is considered a mandatory feature of the system and is included in the overall structure of communication management, defining the connection and positions on the level of society, investors, creation of a brand, and image of general education organizations (Atrashenko, 2012). Thus, the main difference of foreign general education organizations - is a high public participation (council of parents, founding parties, and so forth) in the life of educational institutions, and as a consequence a continued support of information transparency in order to attract financial and other resources. In addition, the organization of information transparency abroad is connected with publication of annual reports on the activity of the general educational institution structured on the principle of the annual account on definite indicators of the educational process.

\subsection{The Research Hypothesis}

Providing free access to information of public importance, information transparency of the authorities and social services organizations constitute the major hallmarks of the rule of law; serve the purpose of improving the quality and efficiency of educational services (Konstantinovsky et al., 2006). A characteristic feature of federal public administration is constant conscientious participation and interaction in administering education of all educational agents. In this aspect, the information transparency of vocational and higher educational institutions, as a reflection of its status for the interested agents of the educational system, determines the availability of educational organizations to federal public administration.

\section{Experimental}

\subsection{The Objectives of the Research}

We have identified the following research objectives: 1) to determine the positions of educational agents with regard to the criteria of educational institutions informational transparency; 2) to develop information realm of vocational and higher educational organization, complying with all the stakeholders; 3) to assess the current status of vocational and higher educational institutions from the perspective of informational transparency.

\subsection{Theoretical and Empirical Methods}

To test the research hypotheses theoretical methods (analysis, synthesis of the subject domain information) were used and empirical methods (expert methods, methods of mathematical statistics, internet monitoring, and content analysis).

\subsection{The Basis of the Research}

The research was conducted on the basis of vocational and higher education institutions portals assessment. In total 20 top universities in the Russian Federation and the Republic of Tatarstan, 68 vocational training institutions of the Volga Federal District in the Russian Federation and Tatarstan Republic have been considered. 


\subsection{The Stages of the Research}

The research was conducted in three stages:

At the first stage from the perspective of stakeholders the educational institutions information transparency indicators were identified on the basis of their survey and analysis of regulatory documents. The educational institution information realm was structured, which serves as tools for evaluating the information transparency.

At the second stage educational institutions web portals were internet-monitored on the basis of the information realm assessment and a content analysis of the submitted documents. The results of the diagnostics were obtained.

At the third stage the research results were generalized and systematized, the conclusions were drawn about the readiness of educational institutions for the transition to federal public administration.

\subsection{Proceedings and Description of the Experiment}

In the initial phase of the research the legally defined provisions of information transparency of educational institutions were analyzed (Article 29), being required for the disclosure. The list contains 33 items related to the strategic, tactical and operative administration of the educational institution current status: 1) information about the creation, management, educational programs, the number of students, teaching staff, material and technical equipment, and so on; 2) copies of policy papers and plans of the educational institution; 3) a report on the results of self-surveys; 4) documentation on the procedure for rendering chargeable educational services; 5) regulations of the authorities exercising state control (supervision) in the education field, reports on the execution of such regulations and others.

Further a survey was conducted among the stakeholders of the educational system (students of vocational and higher education institutions (158 people); employees of vocational and higher education institutions (teaching staff, 82 people); potential employers ( 22 people); parents or student representatives ( 96 people)) to identify the information of interest to them and the possibility to participate in federal public administration of the educational institution.

For each of the groups the necessary information needs were identified, listed in Table 1 . The importance of the information needs was estimated on the basis of the average value ranking, according to the respondents' answers. Initially, the questions were open, i.e. the respondents themselves diagnosed groups of information needs, and then according to the importance the ranking of the responses was carried out by the same respondents (10 point scale).

Table 1. Information needs of educational institutions stakeholders

\begin{tabular}{|c|c|c|c|}
\hline $\begin{array}{l}\text { Evaluation of } \\
\text { employers } \\
\text { (rating) } \\
\text { informational } \\
\text { composition }\end{array}$ & $\begin{array}{l}\text { Evaluation of society } \\
\text { (rating) informational } \\
\text { composition }\end{array}$ & $\begin{array}{l}\text { Evaluation of students } \\
\text { (rating) } \\
\text { composition }\end{array}$ & $\begin{array}{l}\text { Evaluation of } \\
\text { (rating)informational } \\
\text { composition }\end{array}$ \\
\hline $\begin{array}{ll}\text { Rating } & \text { of } \\
\text { educational } & \\
\text { institution }(10) & \end{array}$ & $\begin{array}{l}\text { Rating of educational } \\
\text { institution (10) }\end{array}$ & $\begin{array}{l}\text { Organizational information } \\
(10)\end{array}$ & Organizational information (10) \\
\hline $\begin{array}{l}\text { Annual report of } \\
\text { the educational } \\
\text { institution (10) }\end{array}$ & $\begin{array}{l}\text { Annual report of the } \\
\text { educational institution }(10)\end{array}$ & $\begin{array}{l}\text { Annual report of the } \\
\text { educational institution }(10)\end{array}$ & $\begin{array}{l}\text { Annual report of the educational } \\
\text { institution (10) }\end{array}$ \\
\hline $\begin{array}{l}\text { Federal State } \\
\text { Educational } \\
\text { Standard and the } \\
\text { list of professions } \\
\text { (10) }\end{array}$ & $\begin{array}{l}\text { Federal State Educational } \\
\text { Standard and the list of } \\
\text { professions (10) }\end{array}$ & $\begin{array}{l}\text { Federal State Educational } \\
\text { Standard and the list of } \\
\text { professions }(8.21)\end{array}$ & $\begin{array}{l}\text { Federal State Educational Standard } \\
\text { and the list of professions (10) }\end{array}$ \\
\hline $\begin{array}{l}\text { Achievements of } \\
\text { educational } \\
\text { institutions } \\
\text { teachers (5.667) }\end{array}$ & Teaching staff (8.09) & Teaching staff (8.97) & Teaching staff (9.54) \\
\hline
\end{tabular}




\begin{tabular}{|c|c|c|c|}
\hline 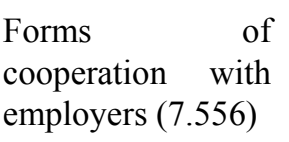 & Social support (10) & Social support (10) & $\begin{array}{l}\text { Trends of scientific research work } \\
(8.78)\end{array}$ \\
\hline $\begin{array}{l}\text { The number of } \\
\text { graduates } \\
\text { according to their } \\
\text { specialization } \\
\text { (annually) ( } 7.778 \text { ) }\end{array}$ & $\begin{array}{l}\text { Curriculum documents / } \\
\text { Instructional materials on } \\
\text { the disciplines (8.13) }\end{array}$ & $\begin{array}{l}\text { Curriculum documents / } \\
\text { Instructional materials on } \\
\text { the disciplines }(8.53)\end{array}$ & $\begin{array}{l}\text { Curriculum documents } \\
\text { Instructional materials on the } \\
\text { disciplines (10) }\end{array}$ \\
\hline $\begin{array}{l}\text { The number of } \\
\text { potential } \\
\text { applicants } \\
\text { (annually) (6.444) }\end{array}$ & $\begin{array}{l}\text { The number of potential } \\
\text { applicants (annually) ( } 9 . \\
\text { 95) }\end{array}$ & $\begin{array}{l}\text { Extracurricular educational } \\
\text { programs, } \\
\text { scientific research works } \\
(9.23)\end{array}$ & $\begin{array}{l}\text { Extracurricular } \\
\text { programs, students, } \\
\text { research works (9.64) }\end{array}$ \\
\hline $\begin{array}{l}\text { Topics of course } \\
\text { works } \\
\text { graduation } \\
\text { dissertations } \\
(6.778)\end{array}$ & $\begin{array}{l}\text { The regulations, constituent } \\
\text { documents, certificates, } \\
\text { diplomas samples }(9.7273)\end{array}$ & $\begin{array}{l}\text { Extracurricular } \\
\text { (10) }\end{array}$ & $\begin{array}{l}\text { Achievements of students in } \\
\text { educational and extracurricular } \\
\text { activities }(8.77)\end{array}$ \\
\hline \multirow[t]{4}{*}{$\begin{array}{l}\text { Student } \\
\text { achievement in the } \\
\text { educational } \\
\text { institution }(8.778)\end{array}$} & $\begin{array}{l}\text { Student achievement in the } \\
\text { educational institution } \\
(8.09)\end{array}$ & Academic curriculum (7.82) & Professions curriculum (10) \\
\hline & $\begin{array}{l}\text { Results of the entrance tests } \\
\text { (10) }\end{array}$ & $\begin{array}{l}\text { Professions and groups } \\
\text { rating }(7.67)\end{array}$ & $\begin{array}{l}\text { Professions, groups and students } \\
\text { rating }(7.62)\end{array}$ \\
\hline & $\begin{array}{l}\text { Types of student activities } \\
(9.5)\end{array}$ & $\begin{array}{l}\text { The procedure for rendering } \\
\text { chargeable } \\
\text { services }(9.77)\end{array}$ & Digital library (8.78) \\
\hline & $\begin{array}{l}\text { The educational institution } \\
\text { head's, administrative } \\
\text { offices' virtual reception } \\
\text { hall (deans' offices) (10) }\end{array}$ & Digital library (9.39) & \\
\hline
\end{tabular}

Analysis of the obtained data highlighted the information realm of the educational institution transparency and supplemented legally defined positions (Article 29 of the Law on Education of the Russian Federation) by the provisions of interest to stakeholders of the educational system. The identified data on the basis of the expert survey showed a high correlation of different agency groups' indicators, which allow us to construct the educational institution information realm and on the basis of these provisions to carry out interaction of vocational education agents.

The obtained indicators of information transparency formed the basis for further research on the status of vocational and higher education institutions.

\section{Results}

\subsection{Internet Monitoring of Information Transparency Mechanism}

Modern educational institutions have a sufficient level of material and technical support to create their own information resources, to develop and continuously update their own websites. As a rule, educational institutions independently develop websites and carry out their continuous updating in accordance with the decided internal policy defined by the head of the institution.

In some regions of the Russian Federation, for example, in the Republic of Tatarstan, a unique information system has been developed for general, further and vocational education institutions - "Electronic Education in the Republic of Tatarstan", which includes a unified system of access to educational institutions' information resources and a common set of indicators. This system laid the foundation for organizing a common educational space, which according to the developers' plan should become the Internet-community with the participation of teachers, students, their parents and other memebers in the educational process. 
Internet-monitoring is an analysis of educational institutions' websites (or shared information systems), at that the analysis is carried out both in terms of public information availability (in accordance with the identified information realm) and content analysis of the data presented on the basis of the information and communication completeness principles, the feedback and relevant information for its users. The obtained information is grouped into the database for providing the possibility to determine the dynamics of the situation development.

\subsection{The Experimental Results on the Analysis of Higher Education Institutions' Information Transparency}

By reference to the sites of higher education institutions (10 top universities of the Russian Federation and 10 top universities in the Republic of Tatarstan (RT)) the information transparency indicators status has been assessed and content - analysis of the documents has been carried out.

The analysis of the Russian universities' status of availability for innovation (included in the best universities in Russia according to Expert RA (top ten)) and the leading universities of the RT (10 universities) gave the following results: the presence of policy papers in $100 \%$ of cases, while it should be noted that the actual possible mission and certain criterion-strategic guidelines were established in $60 \%$ of higher institutions. The system of indicators of operative administration is hidden from the agents of educational institutions, or absent at all (spelled out in $11.8 \%$ of the surveyed organizations). As for management models mostly (82\%) a project-organizational model was selected, where as projects the areas of research activities come to the fore, the educational activities are described by the organizational model with a standard control and learning outcomes assessment system, sometimes with a rating system (68\%). The process administration model adopted in $17.647 \%$ of the reviewed educational institutions is closely related to the quality management system operation and directly affects the educational institution's rating (the first two positions in the top ten). In general, the provisions of information transparency are observed highly enough in the top ten universities of the Russian Federation (on average about 90\%) and not enough in RT universities (on average 70\%). To assess the development of information transparency status the same educational institutions were tested 1 year after, the analysis showed a slight increase in public information $(1.5 \%$ in higher schools of the Russian Federation and $2.5 \%$ in the RT universities).

In contrast to Western universities, this analysis showed a high inertness of the vocational education agents in public administration (consumption, but not participation), the provided information allows obtaining findings about processes, but does not permit participation in administering educational structures and systems, demonstrates a low enough focus on consumers of educational services: students, their parents, teachers, representatives of business and society in general, which significantly reduces the availability of higher education institutions for innovations. It is necessary to develop the practice of studying real expectations and needs of the population in the education area, to carry out a dialogue with customers and potential investors about the range, accessibility and quality of the educational services being delivered.

\subsection{The Experimental Results on the Analysis of Vocational Education Institutions' Information Transparency}

Investigation of vocational educational institutions (secondary vocational education (SVE)) has made it possible to draw the following conclusions:

Comparison of SVE in Volga Federal District (VFD) and Republic of Tatarstan (25 and 43, a total of 68) in respect of the information transparency aspect showed that the Republic of Tatarstan is a leader in terms of information infrastructure. The created educational portal edu.tatar.ru contains the possibility of obtaining information about all institutions of general, professional and further education in RT. A major shortcoming of the current situation is that some SVE institutions, while having their own website and standardized pages on edu.tatar.ru, do not synchronize information (57\%) and wherewith significantly reduce the value of the information and prevent processing it.

In general, the provisions of information transparency are observed in the following proportions: $47 \%$-in the VFD, 63\% - in the RT, indicating the insufficient availability level of SVE institutions for federal public administration, a low level of educational agents' awareness, reducing the potentialities of educational institutions.

Practically absence of (100\%) educational institutions' virtual reception offices, which are of interest to all the agents of vocational education, indicates insufficient work level with education agents in general;

Low level of academic preparedness of SVE institutions (17\%-VFD, 28\%-RT);

At the time of the survey, only $38 \%$ of SVE institutions had policy papers in full, $21 \%$ - the documentation was being developed, the rest (41\%)—was absent. 
Thus, educational organizations of SVE in order to improve and enhance the readiness for innovation should carry out the development of activities strategy, increase the participation of vocational education agents in the education administration (defining the forms and methods), ensure openness and transparency of educational activities, and raise public awareness about the administrative efficiency over a particular period of time. The main objective in the present period-is to determine the legal and regulatory space of federal public administration, to detect problems of using and establishing the legal/regulatory framework in educational institutions and public organizations, analyze the existing practices, identify risks in the implementation of various deployment scenarios of federal public administration in educational institutions and generally in the education system.

\section{Discussions}

The designed system of federal public administration should be aimed at creating standards of educational activities and the conditions for realizing the potential in the education development.

This task can be fulfilled provided that the Federal Public Administration will not be seen as a pyramidal hierarchical structure (as at present), but as a horizontal system of relationships and responsibilities.

The characteristic features of the new experience in exercising federal public educational administration and of social partnership involving education at the regional and municipal levels are the education entities' reconsideration of the public sphere significance in education and educational administration, consideration of the public sphere not as something interfering in the work, and not only as a source of additional resources or professionals' administrative errors corrector, but as an equal entity and a partner having own interests and the right to defend them.

\section{Conclusions}

We have to admit that civil society is currently still insufficiently organized. This is a real obstacle to the inclusion of civil society representatives (local communities) into an active and responsible partnership with authority in the development and educational administration matter.

The formation of federal public education administration involves integration of the following areas of work:

- Ensuring information transparency of the education system, which is a priority of modern educational policy in Russia and the formation of the legal/regulatory framework to ensure transparency and accessibility of information about the education system;

- Democratization of the educational administration and public authorities' activities;

- Development of self-regulating associations of participants in educational activities (professional associations of educators, self-governing bodies of all levels);

- Organization of public authorities for educational administration, which represent all segments of the population.

\section{Acknowledgments}

The authors thank all participants of this study for their kind cooperation.

\section{References}

Atrashenko, A. N. (2012). Openness and self-organization of education systems. Journal of Educational Policy, 1, $36-42$.

Batsyn, V. K. (2009). Expansion of public participation in the management of education. Journal of Eureka, 1, 61-73.

Bochkarev, V. I. (2003). Conceptual bases of state-public management of general education in Russia. Journal of Management in Education, 3, 9-18.

Bolotov, V. A., \& Waldman, I. A. (2012). Informing the various target groups as a condition of the effective use of assessment results of educational achievements of students. Journal Problems of modern education, 6, 187-202.

Danilova, E. E. (2002). Information development of social systems (p. 130). Moscow "RIP_holding" publishing.

Grishina, I. V. (2007). School information report: Toolkit for managers of educational institutions (p. 304). SPb KARO publishing.

Jamil, S. (2009). Growing emphasis on accountability: Progress or dubious blessing? Journal of issues of education, 2, 66-87. 
Kellagann, T. et al. (2014). Using the results of the national assessment of educational achievements (p. 248). Moscow Logos publishing.

Konstantinovsky, D. L., Agranovich, M. L., \& Dymarskaya, O. J. (2006). From the collection of statistical data-Information support to decision-making (p. 160). Moscow Logos publishing.

Kosaretsky, S. G. et al. (2010). Public education management from precedent to the institution. In Research and development (p. 372). Moscow Publisher "Verdana".

Shimutina, E. N. (2013). Control Tips: Problems, prospects, opportunities for education authority. Journal of educational administration, 2(29), 4-10.

Tsyvin, V. M. (2008). Information policy educational institution: Toolkit (p. 104). SPb.: SEI APE SPb TSPKS "Regional Center for Educational Quality Assessment and Information Technology".

Waldman, I. A. (2010). How to ensure the information transparency of the education system? Journal of issues of education, 7, 85-93.

Webster, F. (2004). Theories of the information society (p. 400). Moscow Aspect-Press.

Zhurenkov, K. A. (2007). The idea of an open society in the pages of Russian media. Journal Moscow University Bulletin, 4, 128-139.

\section{Copyrights}

Copyright for this article is retained by the author(s), with first publication rights granted to the journal. This is an open-access article distributed under the terms and conditions of the Creative Commons Attribution license (http://creativecommons.org/licenses/by/3.0/). 